\section{Effects of Mycorrhizal Colonization on Nitrogen and Phosphorus Leaching from Nursery Containers}

\author{
Lea Corkidi ${ }^{1}$ \\ Department of Botany and Plant Sciences, University of California, Riverside, \\ CA 92521; and Tree of Life Nursery, 33201 Ortega Highway, San Juan \\ Capistrano, CA 92675
}

Donald J. Merhaut and Edith B. Allen

Department of Botany and Plant Sciences, University of California, Riverside, CA 92521

James Downer

University of California Cooperative Extension, 669 County Square Drive, Suite 100, Ventura, CA 93003

\section{Jeff Bohn and Mike Evans}

Tree of Life Nursery, 33201 Ortega Highway, San Juan Capistrano, CA 92675

Additional index words. arbuscular mycorrhizal fungi, Best Management Practices, controlledrelease fertilizer, plant growth

\begin{abstract}
Our goal was to investigate the effects of mycorrhizal colonization on nitrogen (N) and phosphorus (P) leaching from plants grown in nursery containers. We compared the growth response and the content of nitrate $\left(\mathrm{NO}_{3}\right)$, ammonium $\left(\mathrm{NH}_{4}\right)$, and orthophosphate, in leachates collected from mycorrhizal (AM) and nonmycorrhizal (NonAM) plants of the fast-growing perennial, Encelia californica Nutt. (california sunflower), and the slow-growing woody shrub, Rhus integrifolia (Nutt.) Brewer \& S. Watson (lemonade berry). Plants were grown for 8 weeks with no fertilizer or with $0.88 \mathrm{~g}$ (half rate) and $1.76 \mathrm{~g}$ (full rate) of $18 \mathrm{~N}-2.6 \mathrm{P}-9.9 \mathrm{~K}$ Osmocote (18-6-12, 6-7 month longevity at $26{ }^{\circ} \mathrm{C}$,

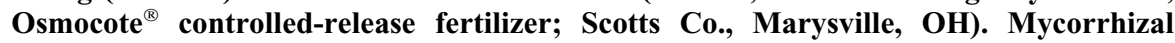
colonization increased the growth and nutrient uptake of $E$. californica and $R$. integrifolia but was more effective at decreasing nutrient leaching from containers with $E$. californica. Mycorrhizal colonization contributed to reduce the content of $\mathrm{NO}_{3}, \mathrm{NH}_{4}$, and orthophosphate by up to $65 \%$ in leachates from $E$. californica grown with half rate of Osmocote and up to $70 \%$ to $80 \%$ in those from plants grown in full rates of Osmocote. In contrast, only the leachates from AM plants of $R$. integrifolia grown without fertilizer had generally lower nutrient content than those from NonAM plants. Leachates collected from AM plants grown in half rates of Osmocote had less $P$ but no less $N$, and there were mostly no significant differences in the leachate content of $\mathrm{NO}_{3}, \mathrm{NH}_{4}$, and orthophosphate from AM and NonAM plants of $R$. integrifolia grown in full rates of Osmocote. However, mycorrhizal colonization reduced the fertilizer requirement to achieve maximum growth in both species. AM plants of $\boldsymbol{E}$. californica and $\boldsymbol{R}$. integrifolia grown with half rates of Osmocote had greater dry weight than the NonAM ones grown in full rates of Osmocote. Our study shows that mycorrhizal colonization can reduce $N$ and $P$ leaching either by increasing nutrient uptake or by allowing the use of lower fertilizer rates.
\end{abstract}

\footnotetext{
Received for publication 23 Mar. 2011. Accepted for publication 26 Aug. 2011.

We thank Ramiro Rodríguez, Salvador Zamarripa, Sinfarrosa Tampa, and Antonio Rodríguez for technical assistance; and María Esther Sánchez Coronado for valuable discussions. Special thanks to Milt McGiffen and Gene Ratcliffe for carefully reviewing the manuscript.

Mention of a trademark, proprietary product, or vendor does not constitute a guarantee or warranty of the product by the authors and does not imply its approval to the exclusion of other products or vendors that may also be suitable.

${ }^{1}$ To whom reprint requests should be addressed; e-mail lea.corkidi@ucr.edu.
}

Mitigation of $\mathrm{N}$ and $\mathrm{P}$ runoff is a major goal of the nursery industry. Woody and herbaceous ornamental plant production may be a significant source of surface water and groundwater contamination (Mangiafico et al., 2009; Thompson et al., 2002). Plant production in containers is intensive, one acre of land can be occupied by thousands of containers, and nursery cultural practices such as the use of soilless mixes, high fertilizer rates, and frequent irrigation are highly conducive to nutrient leaching (Juntunen et al., 2002; Million et al., 2007).

A number of Best Management Practices have been proposed to maximize production and minimize water contamination from runoff and leaching losses. These practices vary with particular nursery conditions but most encompass proper irrigation and fertilizer programs to optimize nutrient use efficiency (Lea-Cox et al., 2010; Yeager et al., 2010).

Mycorrhizal technology can also be included as an important component of nurseries' cultural programs to reduce nutrient runoff while maintaining plant quality and yield (Amaya-Carpio et al., 2009; Sousa et al., 2011). Arbuscular mycorrhizal fungi are a group of microorganisms that colonize the roots of most plants, establishing a mutually beneficial relationship. They develop an extraradical mycelium that enhances the plant's ability to acquire mineral nutrients and water (Liu et al., 2007). The hyphae of arbuscular mycorrhizal fungi take up substantial amounts of $\mathrm{P}$ and $\mathrm{N}$ from different sources in the soil (Atul-Nayyar, et al., 2009; Govindarajulu et al., 2005; Hodge et al., 2001), although their growth, development, and ability to acquire nutrients vary among different species, and their activity is related to growing medium conditions and host plants (Liu et al., 2007). Although few studies have investigated the effects of mycorrhizal colonization on $\mathrm{N}$ and $\mathrm{P}$ leaching in nursery conditions (e.g., Zinati et al., 2007), Haines and Best (1976) showed decreased leaching of ammonium $\left(\mathrm{NH}_{4}\right)$ and nitrate $\left(\mathrm{NO}_{3}\right)$ from mycorrhizal plants of Liquidambar styraciflua L. grown in soil. Asghari et al. (2005) found decreased P leaching from mycorrhizal plants of Trifolium subterraneum L. grown in soil at low P levels but not at high $\mathrm{P}$ levels. Van der Heijden (2010) reported that grassland microcosms with mycorrhizal plants of Festuca ovina L., Anthoxanthum odoratum L., or Poa pratensis L. lost $60 \%$ less $\mathrm{P}, 7.5 \%$ less $\mathrm{NH}_{4}$, although not less $\mathrm{NO}_{3}$, than the nonmycorrhizal control microcosms. Asghari and Cavagnaro (2011) found lower levels of $\mathrm{NO}_{3}, \mathrm{NH}_{4}$, and $\mathrm{P}$ in soils and leachates collected from containers with mycorrhizal plants of Phalaris aquatica L. than in those collected from containers with nonmycorrhizal plants.

Our goal was to investigate the effects of mycorrhizal colonization on the content of $\mathrm{N}$ and $\mathrm{P}$ in leachates from plants grown in nursery conditions. We compared the growth response and the content of $\mathrm{NO}_{3}, \mathrm{NH}_{4}$, and orthophosphate in leachates collected from AM and NonAM plants of the fast-growing perennial, Encelia californica, and the slowgrowing woody shrub, Rhus integrifolia, grown in a standard nursery mix with different levels of fertilizer. The following specific questions were addressed: 1) does mycorrhizal colonization significantly decrease $\mathrm{N}$ and $\mathrm{P}$ leaching? and if so, 2) is this response related to plant growth, to the extent of mycorrhizal colonization, and/or to the concentration of fertilizer in the growing medium?

\section{Materials and Methods}

\section{Plant material}

Two California native plants were selected based on their contrasting growth rates. 
Encelia californica (california sunflower) is an evergreen subshrub that grows quickly to $1.5 \mathrm{~m}$ high and wide. Rhus integrifolia (lemonade berry) is a 1.5 to $3-\mathrm{m}$ tall slow-growing woody perennial shrub or small tree with thick, dull green leaves that cover the plant densely. Both species are important components of the coastal sage scrub and chaparral communities and are widely propagated to be used as ornamentals and for ecological restoration (Newton and Claassen, 2003).

\section{Growth experiment}

To investigate the effects of mycorrhizal colonization on plant growth and $\mathrm{N}$ and $\mathrm{P}$ leaching, an experiment was conducted in a greenhouse at the Tree of Life Nursery in San Juan Capistrano, CA, from June to Aug. 2008. Average maximum and minimum temperatures were $29 / 18{ }^{\circ} \mathrm{C}$ (day/night).

One week-old pre-germinated seedlings of $E$. californica and $R$. integrifolia were transplanted into $8.7 \mathrm{~cm} \times 9.4-\mathrm{cm} 480-\mathrm{mL}$ pots (McConkey, Garden Grove, CA) filled with a potting mix inoculated with one teaspoon of mycorrhizal or nonmycorrhizal inoculants that had been previously incorporated in the planting hole.

\section{Growing medium}

The growing medium was a mixture of redwood bark, pine sawdust, calcined clay, and sand (1:2:1:1 by vol.) steam sterilized for $1 \mathrm{~h}$ on 2 consecutive days. It was amended with $1.19 \mathrm{~kg} \cdot \mathrm{m}^{-3}\left(2 \mathrm{lb} / \mathrm{yd}^{3}\right)$ of dolomite, $0.59 \mathrm{~kg} \cdot \mathrm{m}^{-3}\left(1 \mathrm{lb} / \mathrm{yd}^{3}\right)$ of calcium carbonate, $0.59 \mathrm{~kg} \cdot \mathrm{m}^{-3}\left(1 \mathrm{lb} / \mathrm{yd}^{3}\right)$ of ferrous sulfate, and $0.59 \mathrm{~kg} \cdot \mathrm{m}^{-3}\left(1 \mathrm{lb} / \mathrm{yd}^{3}\right)$ of Sierra Micro$\max ^{\circledR}$ (Scott-Sierra Horticultural Products Co., Marysville, $\mathrm{OH}$ ). Before the incorporation of the fertilizer treatments, this soilless mix had 48, 44, and $112 \mathrm{mg} \cdot \mathrm{kg}^{-1}$ of $\mathrm{N}, \mathrm{P}$, and potassium $(\mathrm{K})$, respectively, and a $\mathrm{pH}$ of 6.8 ( $\mathrm{N}$ and $\mathrm{K}$ were determined by sodium chloride extraction and $\mathrm{P}$ by sodium bicarbonate extraction at the Soil and Plant Laboratory, Inc., Orange County, CA).

\section{Mycorrhizal and nonmycorrhizal inoculum}

Mycorrhizal and nonmycorrhizal inoculants were propagated in pot cultures 4 months before the beginning of the experiment. Seeds of marigold (Tagetes lemmonii Gray) were planted in 1-gallon pots filled with a mixture of calcined clay with root pieces colonized by VAM $80^{\circledR}$ (Tree of Life Nursery) or microwaved sterilized root pieces (for the mycorrhizal and nonmycorrhizal inoculum, respectively). VAM $80^{\circledR}$ consists of at least 60 propagules per cubic centimeter of spores, hyphae, and/or root pieces colonized by a species of Glomus that sporulates intraradically and is propagated for largescale inoculation of California native plants in containers at Tree of Life Nursery. After 4 months of growth, plant tops were removed and the substrate was allowed to dry. The roots were finely chopped and thoroughly mixed with the media to obtain homogeneous inoculants.

\section{Fertilizer treatments}

One week after transplanting, 20 mycorrhizal and nonmycorrhizal pots per species were not fertilized or were top-dressed with $0.88 \mathrm{~g}$ (half rate) or $1.76 \mathrm{~g}$ (full rate) of $18 \mathrm{~N}$ 2.6P-9.9K Osmocote (18-6-12, 6-7 month longevity at $26{ }^{\circ} \mathrm{C}$, Osmocote ${ }^{\circledR}$ controlledrelease fertilizer; Scotts Co., Marysville, $\mathrm{OH}$ ). The fertilizer prills were carefully mixed in the surface of the container and covered with an additional layer of potting mix. The amounts of Osmocote were calculated based on the recommended standard low rates of $4.15 \mathrm{~kg} \cdot \mathrm{m}^{3}$ $\left(7 \mathrm{lb} / \mathrm{yd}^{3}\right)$. The primary plant nutrients derived from this product are ammonium nitrate, ammonium phosphate, calcium phosphate, and potassium sulfate $(9.7 \%$ of the source of nitrogen is $\mathrm{NO}_{3}$ and $8.3 \%$ is $\mathrm{NH}_{4}$ ).

\section{Harvests}

Ten randomly selected plants per treatment were harvested 4 and 8 weeks after transplanting. Shoots were separated from roots and were oven-dried at $70{ }^{\circ} \mathrm{C}$ to record shoot dry weight. Roots were air-dried, weighed, and a subsample of the root system was used to assess the percentage of mycorrhizal colonization. Root pieces were cleared and stained using the technique of Koske and Gemma (1989) and 50 1-cm-long root pieces were mounted in polyvinyl alcohol lactoglycerol on microscope slides. The percentage of mycorrhizal colonization was determined in 100 intersections by the magnified intersection method of McGonigle et al. (1990). The concentration of $\mathrm{N}$ and $\mathrm{P}$ in shoots obtained at the second harvest was determined at the University of California Davis Division of Agriculture and Natural Resources Analytical Laboratory. Total $\mathrm{N}$ and $\mathrm{P}$ shoot content was calculated by multiplying the concentration by the shoot dry weight at the second harvest.

\section{Leachate collection and analysis}

To retain the leachates, 10 replicate plants randomly designated for the final harvest were placed in plastic cups. Leachates from containers were collected weekly, on the same day each week, 30 min after hand watering with $138 \mathrm{~mL}$ of tap water that contained an average of $3 \mathrm{mg} \cdot \mathrm{L}^{-1}$ of $\mathrm{NO}_{3} ; 0 \mathrm{mg} \cdot \mathrm{L}^{-1}$ of $\mathrm{NH}_{4}, \mathrm{P}$, and $\mathrm{K}$; a pH of 7.2 ; and an EC of $0.70 \mathrm{dS} \cdot \mathrm{m}^{-1}$.

Leachate total volumes were recorded and 20-mL sample aliquots were collected in vials and immediately frozen until ready to be analyzed. Solutions were analyzed for $\mathrm{NO}_{3}, \mathrm{NH}_{4}$, and orthophosphate with an Astoria Analyzer (Astoria-Pacific International, Clackamas, OR). Nitrate was analyzed using the colorimetric automated, hydrazine reduction method (Kamphake et al., 1967), $\mathrm{NH}_{4}$ using the colorimetric, automated phenate method, and orthophosphate by the colorimetric, automated ascorbic acid reduction method (U.S. Environmental Protection Agency, 1979). The content of $\mathrm{NO}_{3}, \mathrm{NH}_{4}$, and orthophosphate in leachates was calculated by multiplying the concentration of each ion by the total volume of water collected during 8 weeks.

\section{Experimental design and data analysis}

The study was designed as a $2 \times 3$ factorial with 20 replicates for two harvests per plant species. The two levels of the inoculum were mycorrhizal and nonmycorrhizal, and the three levels in the fertilizer treatment were unfertilized or fertilized with half or full rates of Osmocote. Replicates of each treatment were randomly arranged on a greenhouse bench.

Two-way analysis of variance (ANOVA) with inoculum and fertilizer treatments as factors was performed on plant growth (root, shoot, total dry mass, and root:shoot). The percentages of mycorrhizal colonization were arcsine-square root transformed before statistical analysis with one-way ANOVA. Mean contrasts were performed using Fisher's protected least significant difference with $P \leq$ 0.05 as the level of significance. The content of $\mathrm{NO}_{3}, \mathrm{NH}_{4}$, and orthophosphate obtained during 8 weeks was analyzed by two-way repeated-measures ANOVA. When interactions between fertilizer and inoculum treatments were significant, one-way ANOVA was used to analyze significant differences among fertilizer rates in each inoculum treatment, and the Student's $t$ test was used to analyze differences between mycorrhizal and nonmycorrhizal plants in each fertilizer treatment (Statview; SAS Institute, Inc., Cary, NC).

\section{Results}

\section{Effects of different fertilizer rates on} mycorrhizal colonization

Encelia californica. Plants grown without fertilizer had significantly lower percentages of mycorrhizal colonization than those grown with half rate of Osmocote at the first harvest $(P=0.05)$ and than those grown with half and full rates of Osmocote at the second harvest $(P<0.0001)$. The percentages of mycorrhizal colonization of plants grown with no fertilizer and half and full rates of Osmocote were $18.6 \pm 3.2,35.2 \pm 6.9$, and $26 \pm 6.0$, respectively, 4 weeks after transplanting; and $2 \pm 0.6,30 \pm 3.6$, and $26 \pm 4.4$, respectively, 8 weeks after transplanting.

Rhus integrifolia. There were no significant differences in the percentages of mycorrhizal colonization of $R$. integrifolia obtained in the different fertilizer treatments 4 and 8 weeks after transplanting. The percentages of mycorrhizal colonization of plants grown with no fertilizer and half and full rates of Osmocote were $34.5 \pm 5.9,30.5 \pm 5.5$, and $21.4 \pm 4.5$, respectively, at the first harvest, and $53.9 \pm 5.7,57.3 \pm 5.4$, and $45 \pm 3.3$, respectively, at the second harvest.

\section{Effects of mycorrhizal colonization on plant growth \\ Encelia californica.}

First harvest. The two-way ANOVA indicated significant effects of fertilizer in all the growth response variables and of inoculum in root dry weight and root:shoot ratio 4 weeks after transplanting (F ratios of fertilizer effects were $13.30, P \leq 0.0001$; 3.67, $P \leq 0.05$; and $8.21, P \leq 0.001$, for shoot, root, and total dry weight, respectively; 
and of inoculum effects $4.99, P \leq 0.05$ and $10.54, P \leq 0.05$ for root dry weight and root:shoot, respectively).

Incorporation of fertilizer decreased the root:shoot ratio of both AM and NonAM plants, and mycorrhizal colonization further decreased the root:shoot ratio of plants grown with the full rate of Osmocote. Root:shoot ratios of NonAM plants grown without fertilizer and with half and full rates of Osmocote were $0.61 \pm 0.06,0.49 \pm 0.07$, and $0.39 \pm 0.04$, respectively, and of AM plants $0.52 \pm 0.07$, $0.32 \pm 0.04$, and $0.21 \pm 0.04$, respectively.

Second harvest. Eight weeks after transplanting, the two-way ANOVA indicated significant effects of fertilizer $(\mathrm{F}=154.8, P \leq$ $0.0001)$ but not of inoculum $(\mathrm{F}=0.219)$ on the shoot height of E. californica. Fertilization increased the shoot height of both AM and NonAM plants. However, there were no significant differences between the shoot height of AM and NonAM plants at each fertilizer level (data not shown).

There were significant interactions of fertilizer rate and inoculum treatment in shoot, root, total dry weight, and root:shoot ratio (Table 1). Mycorrhizal colonization increased the shoot, root, and total dry weight of plants grown with half and full rates of Osmocote, but there were no significant differences between the growth of AM and NonAM plants grown without fertilizer (Table 1).
Fertilization with half and full rates of Osmocote significantly reduced the root: shoot ratio of NonAM plants. Mycorrhizal colonization reduced the root:shoot ratio of plants grown without fertilizer but there were no significant differences in the root:shoot ratios of AM and NonAM plants grown in half and full rates of Osmocote at the second harvest (Table 1).

Rhus integrifolia.

First harvest. Four weeks after transplanting, the two-way ANOVA indicated significant effects of fertilizer on shoot height $(\mathrm{F}=10.04, P \leq 0.001)$, root dry mass $(\mathrm{F}=$ $3.33, P \leq 0.05)$, and root:shoot $(\mathrm{F}=3.10, P \leq$ $0.05)$, but only significant effects of inoculum in shoot height $(\mathrm{F}=4.33, P \leq 0.05)$. Addition of fertilizer reduced the root:shoot ratio of AM and NonAM plants grown with either half or full rates of Osmocote, but there were no significant differences between inoculum treatments regardless of fertilizer rate. The root:shoot ratios of NonAM plants grown without fertilizer and with half and full rates of Osmocote were $0.46 \pm 0.04,0.37 \pm 0.05$, and $0.37 \pm 0.02$, respectively, and of AM plants $0.46 \pm 0.04,0.37 \pm 0.04$, and $0.38 \pm$ 0.03 , respectively.

Second harvest. Eight weeks after transplanting, the two-way ANOVA indicated that there were no effects of inoculum or fertilizer on root mass. There were significant interactions of fertilizer and inoculum in shoot, total dry weight, and root:shoot ratio (Table 2). Fertilization with Osmocote increased the growth of AM plants but not the growth of NonAM plants. There were no significant differences in the shoot height, shoot, root, and total dry mass produced by NonAM plants grown without fertilizer or with half and full rates of Osmocote. In contrast, AM plants of Rhus integrifolia that were fertilized with half and full rates of Osmocote had greater shoot and total dry weight than those grown without fertilizer (Table 2). Nevertheless, increasing the amount of Osmocote did not stimulate the growth of AM plants. There were no significant differences in shoot and total dry weight of AM plants grown with half and full rates of Osmocote.

Mycorrhizal colonization decreased the root:shoot ratio of plants grown with half and full rates of Osmocote, but there were no significant differences in the root:shoot ratios of AM and NonAM plants grown without fertilizer (Table 2).

\section{Effects of mycorrhizal colonization on shoot tissue nitrogen and phosphorus}

Encelia californica. The two-way ANOVA indicates that there were interactions between fertilizer and inoculum in the content of $\mathrm{N}$ in shoot tissue and in the content and concentration of $\mathrm{P}$. The percentage of $\mathrm{N}$ significantly increased as the fertilizer rate increased in both

Table 1. Effect of fertilizer rate and mycorrhizal colonization on the growth of Encelia californica 8 weeks after transplanting.

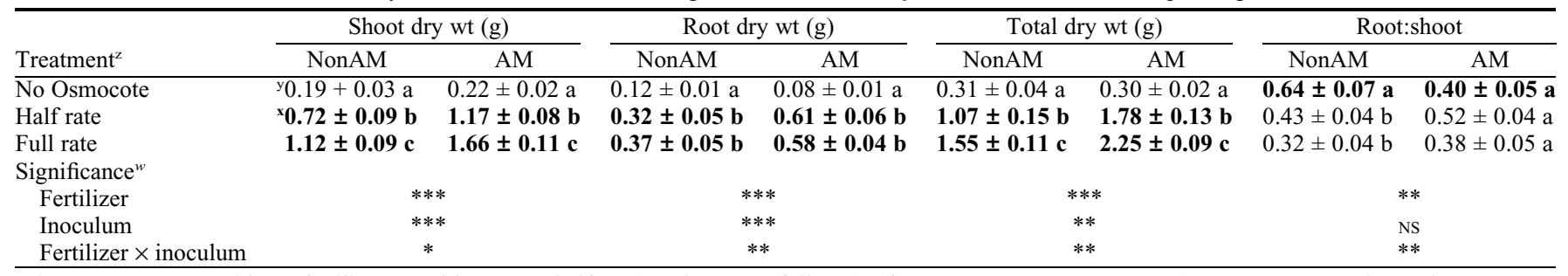

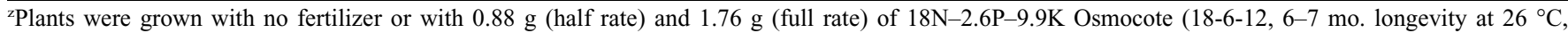
Osmocote $^{\circledR}$ controlled-release fertilizer; Scotts Co., Marysville, OH) and were not inoculated (NonAM = nonmycorrhizal) or were inoculated with VAM $80^{\circledR}$ $(\mathrm{AM}=$ mycorrhizal).

${ }^{y}$ Data represent the mean \pm SE of 10 replicates. Means within a column followed by the same letter are not significantly different at $\alpha=0.05$ as determined by Fisher's protected least significant difference.

${ }^{x}$ Values in bold indicate significant differences between NonAM and AM plants at each fertilizer treatment (across rows) according to the Student's $t$ test at $P \leq$ 0.05 .

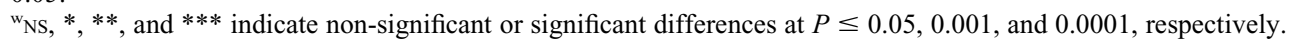

Table 2. Effect of fertilizer rate and mycorrhizal colonization on the growth of Rhus integrifolia 8 weeks after transplanting.

\begin{tabular}{|c|c|c|c|c|c|c|c|c|}
\hline \multirow[b]{2}{*}{ Treatment ${ }^{\mathrm{z}}$} & \multicolumn{2}{|c|}{ Shoot dry wt (g) } & \multicolumn{2}{|c|}{ Root dry wt (g) } & \multicolumn{2}{|c|}{ Total dry wt (g) } & \multicolumn{2}{|c|}{ Root:shoot } \\
\hline & NonAM & $\mathrm{AM}$ & NonAM & $\mathrm{AM}$ & NonAM & $\mathrm{AM}$ & NonAM & AM \\
\hline No Osmocote & ${ }^{\mathrm{y}} 0.34 \pm 0.02 \mathrm{a}$ & $0.29 \pm 0.03 \mathrm{a}$ & $0.12 \pm 0.009 \mathrm{a}$ & $0.11 \pm 0.01 \mathrm{a}$ & $0.47 \pm 0.03 \mathrm{a}$ & $0.40 \pm 0.033 \mathrm{a}$ & $0.36 \pm 0.020 \mathrm{a}$ & $0.39 \pm 0.055 \mathrm{a}$ \\
\hline Half rate & ${ }^{\mathrm{x}} 0.45 \pm 0.06 \mathrm{a}$ & $0.65 \pm 0.06 b$ & $0.14 \pm 0.011 \mathrm{a}$ & $0.12 \pm 0.01 \mathrm{a}$ & $0.59 \pm 0.07 a$ & $0.77 \pm 0.070 b$ & $0.33 \pm 0.019 a$ & $0.19 \pm 0.015 b$ \\
\hline Full rate & $0.43 \pm 0.06 a$ & $0.75 \pm 0.05 b$ & $0.12 \pm 0.014 \mathrm{a}$ & $0.13 \pm 0.01 \mathrm{a}$ & $0.55 \pm 0.07 a$ & $0.87 \pm 0.063 b$ & $0.30 \pm 0.022 a$ & $0.17 \pm 0.012 b$ \\
\hline \multicolumn{9}{|l|}{ Significance $^{\mathrm{w}}$} \\
\hline Fertilizer & \multicolumn{2}{|c|}{$* * *$} & \multicolumn{2}{|c|}{ NS } & \multicolumn{2}{|c|}{$* * *$} & \multicolumn{2}{|c|}{$* *$} \\
\hline Inoculum & \multicolumn{2}{|c|}{$* *$} & \multicolumn{2}{|c|}{ NS } & \multicolumn{2}{|c|}{$* *$} & \multicolumn{2}{|c|}{$* *$} \\
\hline Fertilizer $\times$ Inoculum & \multicolumn{2}{|c|}{$* *$} & \multicolumn{2}{|c|}{ NS } & \multicolumn{2}{|c|}{$* *$} & \multicolumn{2}{|c|}{$* *$} \\
\hline
\end{tabular}

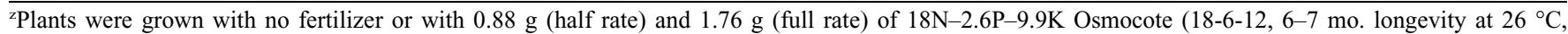

Osmocote ${ }^{\circledR}$ controlled-release fertilizer; Scotts Co., Marysville, OH) and were not inoculated (NonAM = nonmycorrhizal) or were inoculated with VAM $80^{\circledR}$ $(\mathrm{AM}=$ mycorrhizal $)$.

${ }^{y}$ Data represent the mean \pm SE of 10 replicates. Means within a column followed by the same letter are not significantly different at $\alpha=0.05$ as determined by Fisher's protected least significant difference.

${ }^{x}$ Values in bold indicate significant differences between NonAM and AM plants at each fertilizer treatment (across rows) according to the Student's $t$ test at $P \leq$ 0.05 .

${ }^{\mathrm{w}} \mathrm{NS}, *, * *$, and $* * *$ indicate non-significant or significant differences at $P \leq 0.05,0.001$, and 0.0001 , respectively. 
AM and NonAM plants. However, mycorrhizal colonization only increased the concentration of $\mathrm{N}$ in plants grown without fertilizer. The total content of $\mathrm{N}$ of AM plants grown in half and full rates of Osmocote was significantly higher than the N content of NonAM plants, because AM plants had greater biomass (Table 3).

AM plants had significantly larger shoot $P$ concentrations and content than NonAM plants at all fertilizer rates (Table 3 ).

Rhus integrifolia. The two-way ANOVA indicated significant interactions between fertilizer and inoculum in the content and concentration of $\mathrm{N}$ and $\mathrm{P}$ in shoot tissue. AM plants had significantly greater concentrations and content of shoot tissue $\mathrm{N}$ and $\mathrm{P}$ than NonAM plants at all fertilizer levels (Table 4). AM plants grown with half and full rates of Osmocote had approximately double the content of $\mathrm{N}$ and up to four times more $\mathrm{P}$ than NonAM plants.

Increasing the fertilizer rate from half to full rate of Osmocote increased the content of $\mathrm{N}$ of AM plants but not of NonAM plants. There were no significant differences in the shoot tissue $\mathrm{N}$ content of NonAM plants grown with half and full rates of Osmocote, but AM plants grown with a full rate of Osmocote had a higher content of $\mathrm{N}$ than those grown with the half rate (Table 4).

\section{Effects of mycorrhizal colonization on leachate content of nitrogen and phosphorus}

Encelia californica. The two-way ANOVA for repeated measures indicated significant interactions between time and inoculum on the content of $\mathrm{NO}_{3}, \mathrm{NH}_{4}$, and orthophosphate in leachates collected from plants grown without fertilizer and half and full rates of Osmocote (Table 5).

Nitrate- $N$. Leachates collected from AM plants grown without fertilizer and with full rates of Osmocote had significantly lower content of $\mathrm{NO}_{3}$ than those from NonAM plants during the 8 weeks of the experiment. Nitrate content in leachates from mycorrhizal plants grown with half rates of Osmocote was also significantly lower, except in Weeks 1,3 , and 8 (Fig. 1A-C).

The content of $\mathrm{NO}_{3}$ increased from Week 2 to Week 6 from $0.17 \mathrm{mg}$ to $0.41 \mathrm{mg}$ in leachates from NonAM plants grown without fertilizer (Fig. 1A) and from $0.35 \mathrm{mg}$ to 0.78 $\mathrm{mg}$ in those grown with half rates of Osmocote (Fig. 1B). However, the maximum content of $\mathrm{NO}_{3}$ in leachates collected from AM plants grown without fertilizer and with half rate of Osmocote was $0.045 \mathrm{mg}$ and $0.47 \mathrm{mg}$, respectively, also at Week 6 (Fig. 1A-B). Nitrate content in leachates collected from NonAM plants grown with full rate of
Osmocote increased from $0.36 \mathrm{mg}$ at Week 2 to up to $2.11 \mathrm{mg}$ at Week 4 and then declined to $0.63 \mathrm{mg}$ at Week 8 . In leachates from $\mathrm{AM}$ plants, $\mathrm{NO}_{3}$ content fluctuated from $0.19 \mathrm{mg}$ at Week 2 to up to $0.82 \mathrm{mg}$ at Week 5 and decreased to $0.18 \mathrm{mg}$ at Week 8 (Fig. 1C).

Ammoniacal-N. Leachates collected from AM plants grown without fertilizer had less $\mathrm{NH}_{4}$ than those collected from NonAM plants, except in Weeks 2, 5, and 6 (Fig. 2A). Leachates from AM plants grown with half rates of Osmocote also had lower $\mathrm{NH}_{4}$ content from Week 3 to Week 7 . The content of $\mathrm{NH}_{4}$ in leachates from NonAM plants increased from $0.049 \mathrm{mg}$ at Week 2 to 0.111 $\mathrm{mg}$ at Week 6 , whereas the content of $\mathrm{NH}_{4}$ in leachates collected from AM plants only fluctuated from $0.025 \mathrm{mg}$ at Week 2 to 0.036 mg at Week 6 (Fig. 2B). Ammonium content in leachates collected from AM plants grown in full rates of Osmocote was significantly lower than in those from NonAM plants during the first 4 weeks of the experiment. The maximum $\mathrm{NH}_{4}$ content obtained from NonAM and AM plants was $0.29 \mathrm{mg}$ versus $0.07 \mathrm{mg}$, respectively, at Week 3 (Fig. 2C).

Orthophosphate. Leachates collected from AM plants grown without fertilizer had lower content of orthophosphate than those collected from NonAM plants except at Week 2

Table 3. Effect of fertilizer rate and mycorrhizal colonization on the concentration (\%) and content (mg) of nitrogen $(\mathrm{N})$ and phosphorus $(\mathrm{P})$ in shoot tissue of Encelia californica 8 weeks after transplanting.

\begin{tabular}{|c|c|c|c|c|c|c|c|c|}
\hline \multirow[b]{2}{*}{ Treatment $^{\mathrm{z}}$} & \multicolumn{2}{|c|}{$\mathrm{N}(\%)$} & \multicolumn{2}{|c|}{$\mathrm{N}$ (mg/plant) } & \multicolumn{2}{|c|}{$\mathrm{P}(\%)$} & \multicolumn{2}{|c|}{$\mathrm{P}$ (mg/plant) } \\
\hline & NonAM & AM & NonAM & AM & NonAM & $\mathrm{AM}$ & NonAM & AM \\
\hline NoOsmocote & $0.88 \pm 0.04 a^{y, x}$ & $1.41 \pm 0.03$ a & $2.77 \pm 1.08 \mathrm{a}$ & $2.99 \pm 0.17 \mathrm{a}$ & $0.08 \pm 0.00 a$ & $0.57 \pm 0.04 a$ & $0.23 \pm 0.08 a$ & $1.21 \pm 0.07 \mathrm{a}$ \\
\hline Half rate & $1.77 \pm 0.18 \mathrm{~b}$ & $1.90 \pm 0.08 b$ & $10.93 \pm 1.32 b$ & $19.95 \pm 1.02 b$ & $0.11 \pm 0.01$ a & $0.27 \pm 0.01 b$ & $0.71 \pm 0.09 b$ & $2.82 \pm 0.16 b$ \\
\hline Full rate & $2.46 \pm 0.09 \mathrm{c}$ & $2.44 \pm 0.11 \mathrm{c}$ & $24.81 \pm 2.27 c$ & $36.85 \pm 1.92 \mathrm{c}$ & $0.16 \pm 0.01 b$ & $0.22 \pm 0.01 b$ & $1.53 \pm 0.18 c$ & $3.32 \pm 0.21 \mathrm{c}$ \\
\hline \multicolumn{9}{|l|}{ Significance $^{w}$} \\
\hline Fertilizer & \multicolumn{2}{|c|}{$* * *$} & \multicolumn{2}{|c|}{$* * *$} & \multicolumn{2}{|c|}{$* * *$} & \multicolumn{2}{|c|}{$* * *$} \\
\hline Inoculum & \multicolumn{2}{|c|}{$*$} & \multicolumn{2}{|c|}{$* * *$} & \multicolumn{2}{|c|}{$* * *$} & \multicolumn{2}{|c|}{$* * *$} \\
\hline Fertilizer $\times$ inoculum & \multicolumn{2}{|c|}{ NS } & \multicolumn{2}{|c|}{$* *$} & \multicolumn{2}{|c|}{$* * *$} & \multicolumn{2}{|c|}{$* *$} \\
\hline
\end{tabular}

"Plants were grown with no fertilizer or with $0.88 \mathrm{~g}$ (half rate) and $1.76 \mathrm{~g}$ (full rate) of $18 \mathrm{~N}-2.6 \mathrm{P}-9.9 \mathrm{~K}$ Osmocote $\left(18-6-12,6-7 \mathrm{mo}\right.$. longevity at $26^{\circ} \mathrm{C}$, Osmocote ${ }^{\circledR}$ controlled-release fertilizer; Scotts Co., Marysville, $\mathrm{OH}$ ) and were not inoculated (NonAM = nonmycorrhizal) or were inoculated with VAM $80^{\circledR}$ $(\mathrm{AM}=$ mycorrhizal).

${ }^{y}$ Data represent the mean \pm SE of 10 replicates. Means within a column followed by the same letter are not significantly different at $\alpha=0.05$ as determined by Fisher's protected least significant difference.

${ }^{x}$ Values in bold indicate significant differences between NonAM and AM plants at each fertilizer treatment (across rows) according to the Student's $t$ test at $P \leq$ 0.05 .

${ }^{\mathrm{N}} \mathrm{NS}, * * *$, and $* * *$ indicate non-significant or significant differences at $P \leq 0.05,0.001$, and 0.0001 , respectively.

Table 4. Effect of fertilizer rate and mycorrhizal colonization on the concentration (\%) and content (mg) of nitrogen $(\mathrm{N})$ and phosphorus $(\mathrm{P})$ in shoot tissue of Rhus integrifolia 8 weeks after transplanting.

\begin{tabular}{|c|c|c|c|c|c|c|c|c|}
\hline \multirow[b]{2}{*}{ Treatment $^{z}$} & \multicolumn{2}{|c|}{$\mathrm{N}(\%)$} & \multicolumn{2}{|c|}{$\mathrm{N}$ (mg/plant) } & \multicolumn{2}{|c|}{$\mathrm{P}(\%)$} & \multicolumn{2}{|c|}{ P (mg/plant) } \\
\hline & NonAM & $\mathrm{AM}$ & NonAM & $\mathrm{AM}$ & NonAM & AM & NonAM & AM \\
\hline No Osmocote & $0.61 \pm 0.02 a^{y, x}$ & $0.73 \pm 0.02 a$ & $2.09 \pm 0.11 a$ & $2.46 \pm 0.14 a$ & $0.06 \pm 0.002$ a & $0.18 \pm 0.007 a$ & $0.21 \pm 0.011 a$ & $0.62 \pm 0.04 a$ \\
\hline Half rate & $0.92 \pm 0.05 b$ & $1.27 \pm 0.04 b$ & $4.31 \pm 0.34 \mathrm{~b}$ & $7.44 \pm 0.53 b$ & $0.06 \pm 0.006 \mathrm{a}$ & $0.19 \pm 0.005 b$ & $0.27 \pm 0.02 a b$ & $1.15 \pm 0.08 \mathrm{~b}$ \\
\hline Full rate & $1.05 \pm 0.03 c$ & $1.41 \pm 0.03 \mathrm{c}$ & $4.66 \pm 0.40 \mathrm{~b}$ & $9.97 \pm 0.61 \mathrm{c}$ & $0.07 \pm 0.006 a$ & $0.18 \pm 0.004 a$ & $0.30 \pm 0.027 b$ & $1.28 \pm 0.08 \mathrm{~b}$ \\
\hline \multicolumn{9}{|l|}{ Significance $^{w}$} \\
\hline Fertilizer & \multicolumn{2}{|c|}{$* * *$} & \multicolumn{2}{|c|}{$* * *$} & \multicolumn{2}{|c|}{ NS } & \multicolumn{2}{|c|}{$* * *$} \\
\hline Inoculum & \multicolumn{2}{|c|}{$* * *$} & \multicolumn{2}{|c|}{$* * *$} & \multicolumn{2}{|c|}{$* * *$} & \multicolumn{2}{|c|}{$* * *$} \\
\hline Fertilizer $\times$ inoculum & \multicolumn{2}{|c|}{$* *$} & \multicolumn{2}{|c|}{$* * *$} & \multicolumn{2}{|c|}{$*$} & \multicolumn{2}{|c|}{$* * *$} \\
\hline
\end{tabular}

ㄱants were grown with no fertilizer or with $0.88 \mathrm{~g}$ (half rate) and $1.76 \mathrm{~g}$ (full rate) of $18 \mathrm{~N}-2.6 \mathrm{P}-9.9 \mathrm{~K}$ Osmocote $\left(18-6-12,6-7 \mathrm{mo} .10 n g e v i t y\right.$ at $26{ }^{\circ} \mathrm{C}$,

Osmocote ${ }^{\circledR}$ controlled-release fertilizer; Scotts Co., Marysville, OH) and were not inoculated (NonAM = nonmycorrhizal) or were inoculated with VAM $80^{\circledR}$ $(\mathrm{AM}=$ mycorrhizal $)$.

${ }^{\mathrm{y}}$ Data represent the mean $\pm \mathrm{SE}$ of 10 replicates. Means within a column followed by the same letter are not significantly different at $\alpha=0.05$ as determined by Fisher's protected least significant difference.

${ }^{x}$ Values in bold indicate significant differences between NonAM and AM plants at each fertilizer treatment (across rows) according to the Student's $t$ test at $P \leq$ 0.05 .

${ }^{\mathrm{w}} \mathrm{NS}, *, * *$, and $* * *$ indicate non-significant or significant differences at $P \leq 0.05,0.001$, and 0.0001 , respectively. 
(Fig. 3A). The content of orthophosphate in leachates collected from AM plants grown in half rates of Osmocote was also generally lower than from NonAM plants except during the first and eighth weeks. Orthophosphate content in leachates from AM plants fluctuated from $0.002 \mathrm{mg}$ at Week 2 to $0.003 \mathrm{mg}$ at Week 5 , reached its maximum value of $0.013 \mathrm{mg}$ at Week 6 , and declined to $0.006 \mathrm{mg}$ at Week 8 The content of orthophosphate in leachates collected from NonAM plants increased from 0.006 $\mathrm{mg}$ at Week 2, to $0.039 \mathrm{mg}$ at Week 6, and then declined at Weeks 7 and 8 to up to 0.008 mg (Fig. 3B).

The content of orthophosphate in leachates collected from NonAM plants grown with full rates of Osmocote increased from $0.009 \mathrm{mg}$ at Week 1 , to $0.026 \mathrm{mg}$ at Week 5, and then declined to 0.019 at Week 7 . Orthophosphate content in leachates from AM plants increased from $0.004 \mathrm{mg}$ at Week 1 to $0.013 \mathrm{mg}$ at Week 6 and the decreased to $0.01 \mathrm{mg}$ at Week 7 . At Week 8, there were no significant differences in orthophosphate content recovered from AM and

Table 5. F ratios of two-way analysis of variance with repeated measurements of effects of mycorrhizal colonization on the content $(\mathrm{mg})$ of nitrate $\left(\mathrm{NO}_{3}\right)$, ammonium $\left(\mathrm{NH}_{4}\right)$, and orthophosphate in leachates collected from plants of Encelia californica during 8 weeks. ${ }^{\mathrm{z}}$

\begin{tabular}{lcccc}
\hline & Fertilizer treatment & Inoculum & Week & Inoculum $\times$ week \\
\hline $\mathrm{NO}_{3}$ & No Osmocote & $25.919^{* * *}$ & $36.397^{* * *}$ & $20.418^{* * *}$ \\
& Half rate & 4.103 & $102.19^{* * *}$ & $26.201^{* * *}$ \\
& Full rate & 2.70 & $26.09^{* * *}$ & $2.67 *$ \\
& & & \\
$\mathrm{NH}_{4}$ & No Osmocote & $8.647^{*}$ & $26.895^{* * *}$ & $10.312^{* * *}$ \\
& Half rate & $4.357^{*}$ & $24.189^{* * *}$ & $15.728^{* * *}$ \\
& Full rate & $6.537 *$ & $19.723^{* * *}$ & $11.276^{* * *}$ \\
Orthophosphate & & & \\
& No Osmocote & $17.410^{* *}$ & $53.752^{* * *}$ & $65.65^{* * *}$ \\
& Half rate & $11.03^{*}$ & $46.6^{* * *}$ & $19.96^{* * *}$ \\
& Full rate & $17.286^{*}$ & $30.13 * * *$ & $7.91 * * *$ \\
\hline
\end{tabular}

zThere were two levels in the inoculum treatment (mycorrhizal and nonmycorrhizal) and three levels in the fertilizer treatment [no fertilizer, half rate $(88 \mathrm{~g})$, or full rate $(1.76 \mathrm{~g})$ of $18 \mathrm{~N}-2.6 \mathrm{P}-9.9 \mathrm{~K}$ Osmocote $(18-6$ 12, 6-7 mo. longevity at $26^{\circ} \mathrm{C}$, Osmocote ${ }^{\circledR}$ controlled-release fertilizer; Scotts Co., Marysville, OH)]. $*, * *$, and $* * *$ indicate siginificant differences at $P \leq 0.05, P \leq 0.001$, and $P \leq 0.0001$, respectively.
NonAM plants grown in full rates of Osmocote (Fig. 3C).

Rhus integrifolia. The two-way ANOVA with repeated measures indicated significant interactions between time and inoculum on the content of $\mathrm{NO}_{3}, \mathrm{NH}_{4}$, and orthophosphate in leachates collected from plants grown without fertilizer and half and full rates of Osmocote (Table 6).

Nitrate- $N$. Leachates collected from AM plants of $R$. integrifolia grown without fertilizer had significantly lower content of $\mathrm{NO}_{3}$ at all weeks except at Week 6 . The content of $\mathrm{NO}_{3}$ declined from $1.052 \mathrm{mg}$ to $0.42 \mathrm{mg}$ in leachates collected from NonAM plants and from 0.269 to $0.025 \mathrm{mg}$ in those collected from AM plants (Fig. 4A).

There were no significant differences in the content of $\mathrm{NO}_{3}$ recovered from $\mathrm{AM}$ and NonAM plants grown in half rates of Osmocote, except at Week 5, when leachates collected from AM plants had significantly lower $\mathrm{NO}_{3}$ content than those from NonAM plants ( 0.74 versus $0.39 \mathrm{mg}$, respectively), and at Week 8, when leachates recovered from AM plants had significantly higher content of $\mathrm{NO}_{3}$ than those from NonAM plants ( $0.46 \mathrm{mg}$ versus $0.77 \mathrm{mg}$, respectively) (Fig. 4B). There were no significant differences in the content of $\mathrm{NO}_{3}$ in leachates from $\mathrm{AM}$ and NonAM plants grown in full rates of Osmocote (Fig. 4C).

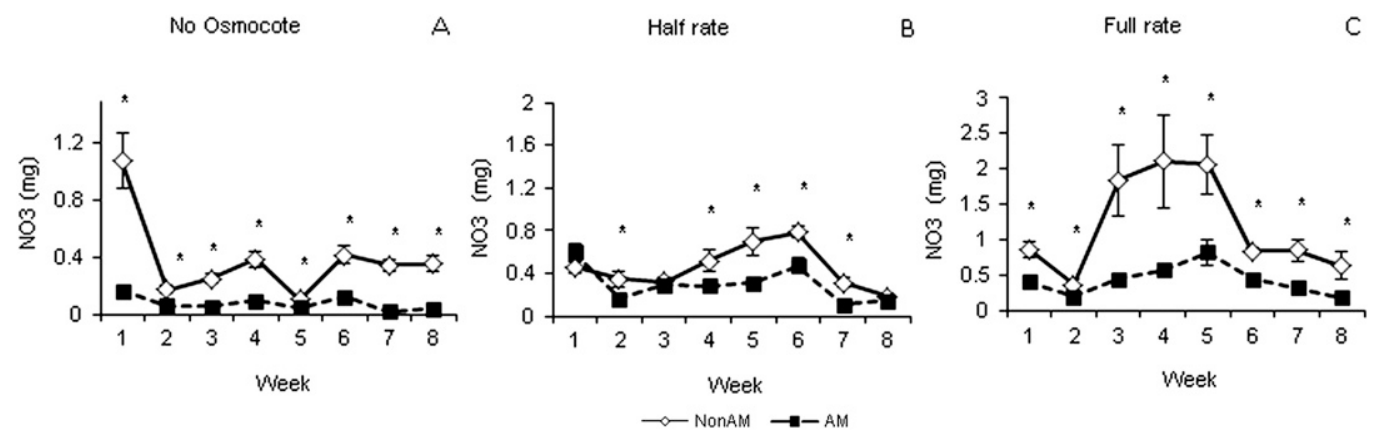

Fig. 1. Content of nitrate $\left(\mathrm{NO}_{3}\right)$ in leachates collected from mycorrhizal (AM) and nonmycorrhizal (NonAM) plants of Encelia californica grown without fertilizer (A) or with $0.88 \mathrm{~g}$ (half rate) $(\mathbf{B})$ and $1.76 \mathrm{~g}$ (full rate) $(\mathbf{C})$ of $18 \mathrm{~N}-2.6 \mathrm{P}-9.9 \mathrm{~K}$ Osmocote $\left(18-6-12,6-7\right.$ month longevity at $26{ }^{\circ} \mathrm{C}$, Osmocote ${ }^{\circledR}$ controlled-release fertilizer; Scotts Co., Marysville, $\mathrm{OH})$. Bars indicate the sE of the mean of 10 replicates $( \pm \mathrm{SE})$. *Above bars indicate significant differences between AM and NonAM plants at $P \leq 0.05$.

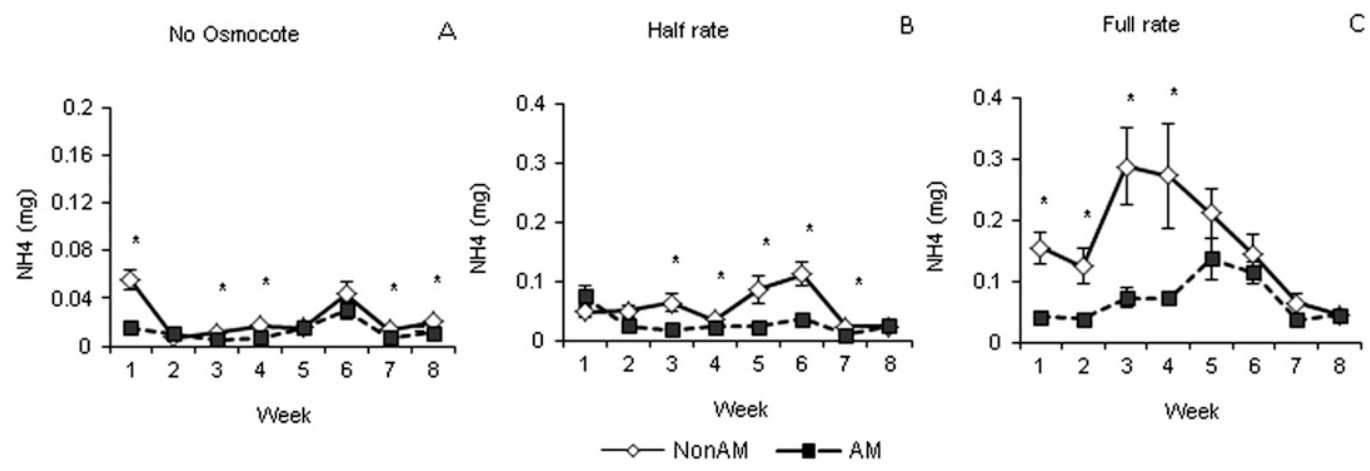

Fig. 2. Content of ammonium $\left(\mathrm{NH}_{4}\right)$ in leachates collected from mycorrhizal (AM) and nonmycorrhizal (NonAM) plants of Encelia californica grown without fertilizer (A) or with $0.88 \mathrm{~g}$ (half rate) $(\mathbf{B})$ and $1.76 \mathrm{~g}$ (full rate) $(\mathbf{C})$ of $18 \mathrm{~N}-2.6 \mathrm{P}-9.9 \mathrm{~K}$ Osmocote $\left(18-6-12,6-7\right.$ month longevity at $26^{\circ} \mathrm{C}$, Osmocote ${ }^{\circledR}$ controlled-release fertilizer; Scotts Co., Marysville, OH). Bars indicate the SE of the mean of 10 replicates $( \pm \mathrm{SE}) .{ }^{*}$ Above bars indicate significant differences between AM and NonAM plants at $P \leq 0.05$. 

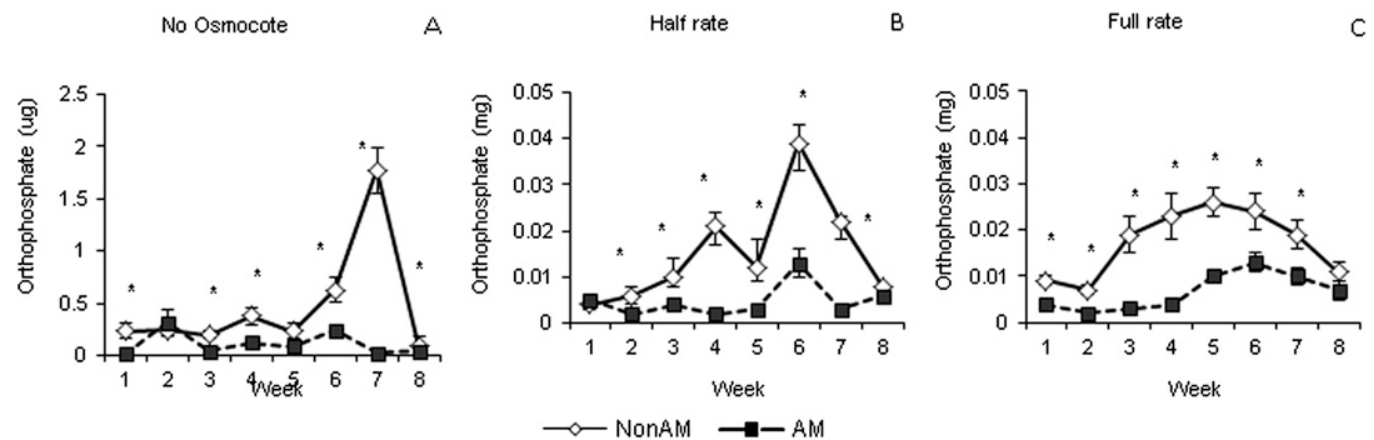

Fig. 3. Content of orthophosphate in leachates collected from mycorrhizal (AM) and nonmycorrhizal (NonAM) plants of Encelia californica grown without fertilizer (A) or with $0.88 \mathrm{~g}$ (half rate) $(\mathbf{B})$ and $1.76 \mathrm{~g}$ (full rate) $(\mathbf{C})$ of $18 \mathrm{~N}-2.6 \mathrm{P}-9.9 \mathrm{~K}$ Osmocote $\left(18-6-12,6-7\right.$ month longevity at $26{ }^{\circ} \mathrm{C}$, Osmocote ${ }^{\circledR}$ controlled-release fertilizer; Scotts Co., Marysville, OH). Bars indicate the SE of the mean of 10 replicates $( \pm \mathrm{SE}) .{ }^{*}$ Above bars indicate significant differences between AM and NonAM plants at $P \leq 0.05$.

Table 6. F ratios of two-way analysis of variance with repeated measurements of effects of mycorrhizal colonization on the content $(\mathrm{mg})$ of nitrate $\left(\mathrm{NO}_{3}\right)$, ammonium $\left(\mathrm{NH}_{4}\right)$. and orthophosphate in leachates collected from plants of Rhus integrifolia collected during 8 weeks at each fertilizer rate. ${ }^{\mathrm{z}}$

\begin{tabular}{llccc}
\hline & Fertilizer treatment & Inoculum & Week & Inoculum $\times$ week \\
\hline $\mathrm{NO}_{3}$ & No Osmocote & $33.837^{* * *}$ & $48.284^{* * *}$ & $15.806^{* * * *}$ \\
& Half rate & 1.440 & $4.613^{* *}$ & $2.776^{*}$ \\
& Full rate & $8.950^{*}$ & $8.439^{* * *}$ & $3.12^{*}$ \\
& & & & \\
& No Osmocote & $65.545^{* * *}$ & $42.447^{* * *}$ & $10.4^{* * *}$ \\
& Half rate & 0.028 & $6.142^{* * *}$ & $2.075^{*}$ \\
& Full rate & 0.313 & $10.466^{* * *}$ & $4.717^{* * *}$ \\
& & & & \\
Orthophosphate & No Osmocote & $8.378^{*}$ & $4.957^{* * *}$ & 1.992 \\
& Half rate & 4.11 & $5.217^{* * *}$ & $2.192^{*}$ \\
& Full rate & $8.18^{*}$ & $9.002^{* * *}$ & $5.908^{* * *}$ \\
\hline
\end{tabular}

${ }^{z}$ There were two levels in the inoculum treatment (mycorrhizal and nonmycorrhizal) and three levels in the fertilizer treatment [no fertilizer, half rate $(88 \mathrm{~g})$, or full rate $(1.76 \mathrm{~g})$ of $18 \mathrm{~N}-2.6 \mathrm{P}-9.9 \mathrm{~K}$ Osmocote $(18-6$ 12, 6-7 mo. longevity at $26^{\circ} \mathrm{C}$, Osmocote ${ }^{\circledR}$ controlled-release fertilizer, Scotts Co., Marysville, OH)]. $*, * *$, and $* * *$ indicate significant differences at $P \leq 0.05, P \leq 0.001$, and $P \leq 0.0001$, respectively.

Ammoniacal-N. Leachates collected from AM plants grown without fertilizer generally had less $\mathrm{NH}_{4}$ than those collected from NonAM plants. Ammonium content declined from $0.16 \mathrm{mg}$ to $0.024 \mathrm{mg}$ in leachates collected from NonAM plants and from $0.056 \mathrm{mg}$ to $0.006 \mathrm{mg}$ in those collected from AM plants (Fig. 5A).

Leachates collected from AM plants grown in half rate and full rates of Osmocote had lower content of $\mathrm{NH}_{4}$ than those from NonAM plants at Week $2(0.061$ versus $0.028 \mathrm{mg}$ and 0.072 versus 0.022 , respectively). However, leachates collected from AM plants at week 8 had more $\mathrm{NH}_{4}$ than those collected from NonAM plants $(0.03$ versus $0.08 \mathrm{mg}$ and 0.103 versus $0.189 \mathrm{mg}$ in leachates from AM and NonAM plants grown with half and full rates of Osmocote, respectively (Fig. 5B-C).

Orthophosphate. Leachates collected from AM plants grown without fertilizer had significantly less orthophosphate than those from NonAM plants at Week 1 and from Weeks 4 to 6. Orthophosphate content increased from $0.003 \mathrm{mg}$ to $0.007 \mathrm{mg}$ from Week 3 to $6 \mathrm{in}$ leachates from NonAM plants, but only from 0.002 to $0.004 \mathrm{mg}$ in those from AM plants (Fig. 6A). The content of orthophosphate recovered from AM plants grown with the half rate of Osmocote was also lower than in those from NonAM plants at Weeks 3 and 4 and Weeks 6 and 7, increasing from 0.006 to
$0.012 \mathrm{mg}$ in leachates from NonAM plants and from 0.003 to $0.007 \mathrm{mg}$ in those from AM plants (Fig. 6B). There were no significant differences in orthophosphate content from AM and NonAM plants grown in full rates of Osmocote until Week 8, when leachates collected from AM plants had significantly more orthophosphate than those collected from NonAM plants $(0.014$ versus $0.071 \mathrm{mg}$ ) (Fig. 6C).

\section{Discussion}

Mycorrhizal colonization increased the growth and nutrient uptake of both $E$. californica and $R$. integrifolia but was more effective at decreasing nutrient leaching from plants of $E$. californica. Leachates collected from AM plants of $E$. californica had significantly less $\mathrm{N}$ and $\mathrm{P}$ than those collected from NonAM plants at all fertilizer rates. Mycorrhizal colonization contributed to reduce the content of $\mathrm{NO}_{3}, \mathrm{NH}_{4}$, and orthophosphate by up to $65 \%$ in leachates from E. californica grown with half rate of Osmocote and up to $70 \%$ to $80 \%$ in those from plants grown in full rates of Osmocote. In contrast, the effects of mycorrhizal colonization on $\mathrm{N}$ and $\mathrm{P}$ content in leachates from plants of $R$. integrifolia were affected by the nutrient type and fertilizer rate. Only the leachates from AM plants grown without fertilizer generally had lower $\mathrm{NO}_{3}, \mathrm{NH}_{4}$, and orthophosphate content than those from NonAM plants. Leachates collected from AM plants grown in half rates of Osmocote generally had less P but no less $\mathrm{N}$, and there were mostly no significant differences in the leachate content of $\mathrm{NO}_{3}$, $\mathrm{NH}_{4}$, and orthophosphate from AM and NonAM plants of $R$. integrifolia grown in full rates of Osmocote.

Decreased nutrient leaching caused by mycorrhizal colonization has been explained by increases in length of AM fungi extraradical hyphae and/or by increased plant mass and nutrient uptake (Asghari et al., 2005; Haines and Best, 1976). It is well known that AM fungal hyphae take up substantial amounts of P (Saito, 2000) and N (Govindarajulu et al., 2005; Jin et al., 2005) from the soil that are allocated to the growth of the fungi or translocated to plants (George, 2000; Hodge et al., 2010). Therefore, mycorrhizal plants take up greater amounts of mineral nutrients and are often larger than nonmycorrhizal plants, which could potentially reduce $\mathrm{N}$ and $\mathrm{P}$ leaching from nursery containers (AmayaCarpio et al., 2005).

Plant growth promotion and increased nutrient absorption could have influenced the effects of mycorrhizal colonization on decreasing $\mathrm{N}$ and $\mathrm{P}$ leaching from containers with E. californica but did not guarantee reductions in nutrient losses from those with $R$. integrifolia at all the fertilizer rates tested. The effects of mycorrhizal colonization on decreasing $\mathrm{N}$ and $\mathrm{P}$ leaching in different plant species might be limited by plant nutrient demand and inherent growth response to nutrient supply. E. californica and R. integrifolia are two species with contrasting growth rates and responses to nutrient availability. E. californica is a perennial subshrub with a fibrous root system (Hellmers et al., 1955), which exhibited the typical plastic response of fast-growing species when subjected to increasing nutrient supply (Gray and Schlesinger, 1983). The growth of E. californica increased as the fertilizer rate increased in both AM and NonAM plants. In contrast, $R$. integrifolia is a woody shrub that showed the pattern of slow-growing perennials with limited responses to increased nutrient availability (Gray and Schlesinger, 1983; Lambers et al., 

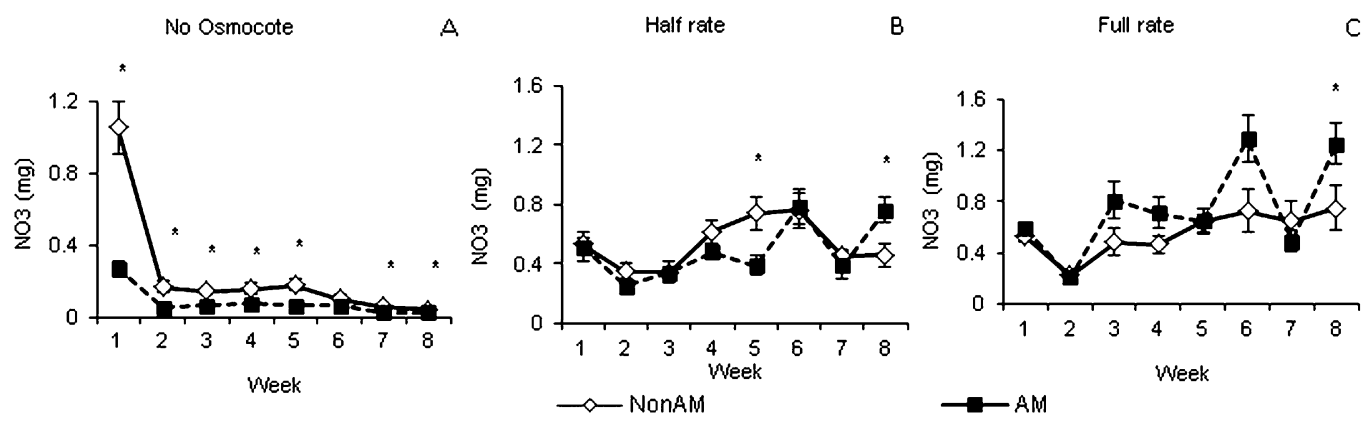

Fig. 4. Content of nitrate $\left(\mathrm{NO}_{3}\right)$ in leachates collected from mycorrhizal (AM) and nonmycorrhizal (NonAM) plants of Rhus integrifolia grown without fertilizer (A) or with $0.88 \mathrm{~g}$ (half rate) $(\mathbf{B})$ and $1.76 \mathrm{~g}$ (full rate) $(\mathbf{C})$ of $18 \mathrm{~N}-2.6 \mathrm{P}-9.9 \mathrm{~K}$ Osmocote $\left(18-6-12,6-7\right.$ month longevity at $26^{\circ} \mathrm{C}$, Osmocote ${ }^{\circledR}$ controlledrelease fertilizer; Scotts Co., Marysville, $\mathrm{OH})$. Bars indicate the SE of the mean of 10 replicates $( \pm \mathrm{SE})$. *Above bars indicate significant differences between $\mathrm{AM}$ and NonAM plants at $P \leq 0.05$.

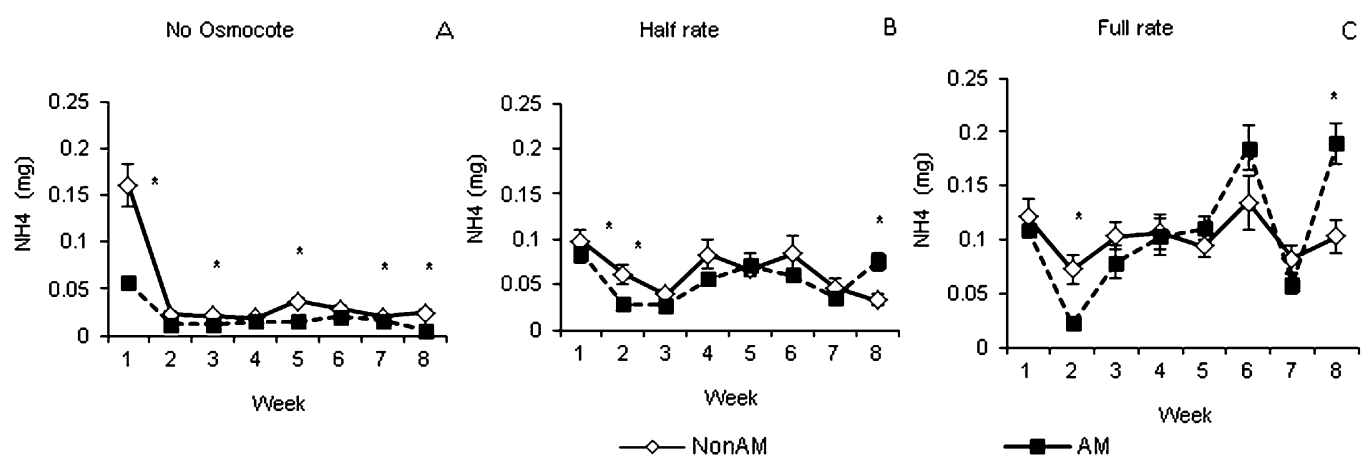

Fig. 5. Content of ammonium $\left(\mathrm{NH}_{4}\right)$ in leachates collected from mycorrhizal (AM) and nonmycorrhizal (NonAM) plants of Rhus integrifolia grown without fertilizer (A) or with $0.88 \mathrm{~g}$ (half rate) $(\mathbf{B})$ and $1.76 \mathrm{~g}$ (full rate) $(\mathbf{C})$ of $18 \mathrm{~N}-2.6 \mathrm{P}-9.9 \mathrm{~K}$ Osmocote $\left(18-6-12,6-7\right.$ month longevity at $26{ }^{\circ} \mathrm{C}$, Osmocote ${ }^{\circledR}$ controlled-release fertilizer; Scotts Co., Marysville, OH). Bars indicate the SE of the mean of 10 replicates $( \pm \mathrm{SE})$. *Above bars indicate significant differences between AM and NonAM plants at $P \leq 0.05$.
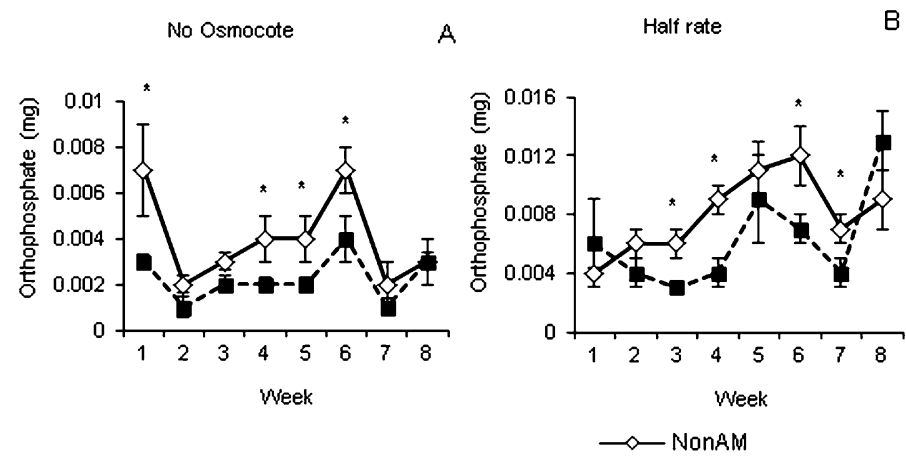

B

Full rate

$\mathrm{C}$

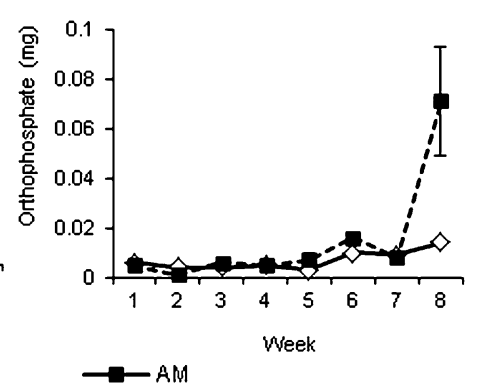

Fig. 6. Content of orthophosphate in leachates collected from mycorrhizal (AM) and nonmycorrhizal (NonAM) plants of Rhus integrifolia grown without fertilizer (A) or with $0.88 \mathrm{~g}$ (half rate) (B) and $1.76 \mathrm{~g}$ (full rate) (C) of $18 \mathrm{~N}-2.6 \mathrm{P}-9.9 \mathrm{~K}$ Osmocote $\left(18-6-12,6-7\right.$ month longevity at $26^{\circ} \mathrm{C}$, Osmocote ${ }^{\circledR}$ controlledrelease fertilizer; Scotts Co., Marysville, OH). Bars indicate the SE of the mean of 10 replicates $( \pm \mathrm{SE})$. *Above bars indicate significant differences between $\mathrm{AM}$ and NonAM plants at $P \leq 0.05$.

1998). Addition of fertilizer did not increase the growth of NonAM plants of R. integrifolia. Half and full rates of Osmocote doubled the growth of AM plants compared with those grown without fertilizer. However, there were no significant differences in the total dry weight of plants grown with half and full rates of fertilizer. Nutrient concentration in the growing medium with Osmocote could have exceeded the capacity of nutrient uptake of even the AM plants of $R$. integrifolia, and therefore mycorrhizal colonization reduced $\mathrm{N}$ and $\mathrm{P}$ leaching in plants grown without fertilizer but not in those grown with half and full rates of Osmocote.

Asghari et al. (2005) also found decreased P leaching from plants of Trifolium subterraneum grown in low $\mathrm{P}$ levels but not in high $\mathrm{P}$ levels. However, in their case, high $\mathrm{P}$ decreased mycorrhizal colonization and the density of extramatrical fungal hyphae.

We did not measure mycorrhizal fungi extraradical hyphal length, but full rates of Osmocote did not decrease the percentages of mycorrhizal colonization for either E. californica or $R$. integrifolia. In fact, plants of $R$. integrifolia had higher percentages of mycorrhizal colonization than those of $E$. californica at all fertility levels, yet mycorrhizal colonization was more effective at reducing nutrient losses in the latter.

Plant growth and/or nutrient uptake increases and nutrient leaching decreases were not synchronous in E. californica. Leachates collected from AM plants of E. californica grown in half and full rates Osmocote generally had lower $\mathrm{N}$ and $\mathrm{P}$ contents during the first 5 weeks of the experiment, although there were no significant differences between 
the growth of AM and NonAM plants at these fertility rates, and AM plants grown with full rates of Osmocote had lower root:shoot ratios than NonAM plants at the first harvest. Moreover, mycorrhizal colonization increased the total dry mass of E. californica grown in half rates of Osmocote by $60 \%$ and in the full rate of Osmocote by $68 \%$ at the second harvest. However, there were no significant differences between $\mathrm{N}$ and $\mathrm{P}$ content in leachates collected from AM and NonAM plants at Week 8. Reduction in nutrient leaching is critical early in the production cycle, because nutrient release of controlled-release fertilizers is relatively high during the first 10 weeks and then decreases (Merhaut et al., 2006).

Although the effects of mycorrhizal colonization were not always reflected in decreased content of $\mathrm{N}$ and $\mathrm{P}$ in leachates from $R$. integrifolia at all fertility rates, the potential still exists to use mycorrhizal inoculation to reduce $\mathrm{N}$ and $\mathrm{P}$ leaching for the propagation of both species, E. californica and $R$. integrifolia, without affecting their plant growth. As shown by other studies (AmayaCarpio et al., 2005; Sousa et al., 2011), mycorrhizal colonization reduced the fertilizer requirement to achieve maximum growth in both species. AM plants of E. californica and $R$. integrifolia grown with half rates of Osmocote had greater dry mass than the NonAM ones grown in full rates of Osmocote. Our study shows that mycorrhizal colonization can reduce $\mathrm{N}$ and $\mathrm{P}$ leaching either by increasing plant nutrient uptake or by allowing the use of lower fertilizer rates.

\section{Literature Cited}

Amaya-Carpio, L., F.T. Davies, Jr., and M.A. Arnold. 2005. Arbuscular mycorrhizal fungi, organic and inorganic controlled-release fertilizers: Effect on growth and leachate of containergrown bush morning glory (Ipomoea carnea ssp. fistulosa) under high production temperatures. J. Amer. Soc. Hort. Sci. 130:131-139.

Amaya-Carpio, L., F.T. Davies, Jr., T. Fox, and C. He. 2009. Arbuscular mycorrhizal fungi and organic fertilizer influence photosynthesis, root phosphatase activity, nutrition, and growth of Ipomoea carnea ssp. fistulosa. Photosynthetica 47:1-10.

Asghari, H.R. and R. Cavagnaro. 2011. Arbuscular mycorrhizas enhance plant interception of leached nutrients. Funct. Plant Biol. 38:219-226.

Asghari, H.R., D.J. Chittleborough, F.A. Smith, and S.E. Smith. 2005. Influence of arbuscular mycorrhizal (AM) symbiosis on phosphorus leaching through soil cores. Plant Soil 275: 181-193.

Atul-Nayyar, A., C. Hamel, K. Hanson, and J. Germida. 2009. The arbuscular mycorrhizal symbiosis links $\mathrm{N}$ mineralization to plant demand. Mycorrhiza 19:239-246.

George, E. 2000. Nutrient uptake, p. 307-343. In: Kapulnik, Y. and D.D. Douds, Jr. (eds.). Arbuscular mycorrhizas: Physiology and function. Kluwer, Dordrecht, The Netherlands.

Govindarajulu, M., P.E. Pfeffer, H. Jin, J. Abubaker, D.D. Douds, J.W. Allen, H. Bucking, P.J. Lammers, and Y. Shachar-Hill. 2005. Nitrogen transfer in the arbuscular mycorrhizal symbiosis. Nature 435:819-823.

Gray, J.T. and W.H. Schlesinger. 1983. Nutrient use by evergreen and deciduous shrubs in southern California. II. Experimental investigations of the relationship between growth, nitrogen uptake and nitrogen availability. J. Ecol. 71:43-56.

Haines, B.L. and G.R. Best. 1976. Glomus mosseae, endomycorrhizal with Liquidambar styraciflua $\mathrm{L}$. seedlings retards $\mathrm{NO}_{3}, \mathrm{NO}_{2}$, and $\mathrm{NH}_{4}$ nitrogen loss from a temperate forest soil. Plant Soil 45:257-261.

Hellmers, H., J.S. Horton, G. Juhren, and J. O'Keefe. 1955. Root systems of some chaparral plants of southern California. Ecology 36:667-678.

Hodge, A., C.D. Campbell, and A.H. Fitter. 2001. An arbuscular mycorrhizal fungus accelerates decomposition and acquires nitrogen directly from organic material. Nature 413:297-299.

Hodge, A., T. Helgason, and A.H. Fitter. 2010. Nutrient ecology of arbuscular mycorrhizal fungi. Fungal Ecol. 3:267-273.

Jin, H., P.E. Pfeffer, D.D. Douds, E. Piotrowski, P.J. Lammers, and Y. Sachar-Hill. 2005. The uptake, metabolism, transport and transfer of nitrogen in an arbuscular mycorrhizal symbiosis. New Phytol. 168:687-696.

Juntunen, M.L., T. Hammar, and R. Rikala. 2002. Leaching of nitrogen and phosphorus during production of forest seedlings in containers. J. Environ. Qual. 31:1868-1874.

Kamphake, L., S. Hannah, and J. Cohen. 1967. Automated analysis for nitrate by hydrazine reduction. Water Res. 1:205.

Koske, R.E. and J.N. Gemma. 1989. A modified procedure for staining roots to detect VA mycorrhizas. Mycorrhizal Res. 92:486-505.

Lambers, H., F. Stuart Chapin, III, and T.L. Pons. 1998. Plant physiological ecology. SpringerVerlag, New York, NY.

Lea-Cox, J.D., C. Zhao, D.S. Ross, T.E. Bilderback, J.R. Harris, S.D. Day, C. Hong, T.H. Yeager, R.C. Beeson, Jr., W.L. Bauerle, A.G. Ritsvey, M. Lorsheider, S. Dickinson, and J.M. Ruter 2010. A nursery and greenhouse online knowledge center: Learning opportunities for sustainable practice. HortTechnology 20:509-517.
Liu, A., C. Plenchette, and C. Hamel. 2007. Soil nutrient and water providers: How arbuscular mycorrhizal mycelia support plant performance in a resource-limited world, p. 37-66. In: Hamel, C. and C. Plenchette (eds.). Mycorrhizal in crop production. Haworth, New York, NY.

Mangiafico, S., J. Newman, D.J. Merhaut, J. Gan, B. Faber, and L. Wu. 2009. Nutrients and pesticides in stormwater runoff and soil water in production nurseries and citrus and avocado groves in California. HortTechnology 19:360 367.

McGonigle, T.P., M.H. Miller, D.G. Evans, J.L. Fairchild, and J.A. Swan. 1990. A new method which gives an objective measure of colonization of roots by vesicular-arbuscular mycorrhizal fungi. New Phytol. 115:495-501.

Merhaut, D.J., E.K. Blythe, J.P. Newman, and J.P. Albano. 2006. Nutrient release from controlledrelease fertilizers in acid substrate in a greenhouse environment: I. Leachate electrical conductivity, $\mathrm{pH}$, and nitrogen, phosphorus, and potassium concentrations. HortScience 41:780-787.

Million, J., T. Yeager, and J. Albano. 2007. Consequences of excessive overhead irrigation on runoff during container production of sweet viburnum. J. Environ. Hort. 25:117-125.

Newton, G.A. and V.P. Claassen. 2003. Rehabilitation of disturbed lands in California: A manual for decision making. California Department of Conservation, California Geological Survey.

Saito, M. 2000. Symbiotic exchange of nutrients in arbuscular mycorrhizas: Transport and transfer of phosphorus, p. 85-106. In: Kapulnik, Y. and D.D. Douds, Jr. (eds.). Arbuscular mycorrhizas: Physiology and function. Kluwer, Dordrecht, The Netherlands.

Sousa, N.R., A.R. Franco, R.S. Oliveira, and P.M.L. Castro. 2011. Ectomycorrhizal fungi as an alternative to the use of chemical fertilizers in nursery production of Pinus pinaster. J. Environ. Manage. (in press).

Thompson, R.B., M. Gallardo, and C. Gimenez. 2002. Assessing risk of nitrate leaching from the horticultural industry of Almeria, Spain. Acta Hort. 571:243-250.

U. S. Environmental Protection Agency. 1979. Methods for chemical analysis of water and wastes. EPA-600/4-70-020. National Environmental Research Center, Cincinnati, OH

Van der Heijden, M.G.A. 2010. Mycorrhizal fungi reduce nutrient loss from grassland ecosystems. Ecology 91:1163-1171.

Yeager, T., J. Million, C. Larsen, and Bob Stamps. 2010. Florida nursery Best management practices: Past, present, and future. HortTechnology 20:82-88.

Zinati, G., J. Dighton, and A.J. Both. 2007. Fertilization, irrigation, and mycorrhizal effects on container-grown nursery crop biomass accumulation and leachate nutrient content. HortScience 42:862. 